\title{
AMINO ACIDS AND FATTY ACIDS PROFILES OF EEL (Monopterus albus) WATER EXTRACTS
}

\author{
Febriyenti*, A. Almahdy and Dwi Mulyani \\ Faculty of Pharmacy, Universitas Andalas, Padang 25163, West Sumatera, Indonesia \\ *E-mail: febriyenti74@gmail.com; febriyenti@phar.unand.ac.id
}

\begin{abstract}
Eel (Monopterus albus) is containing amino acids and fatty acids that important to nutrition and medication. The objective of this study is to investigate the amino acids and fatty acids content of Monopterus albus water extracts. Amino acids contents were analyzed using precolumn derivatization with 6-aminoquinolyl-N-hydroxysuccinimidyl carbamate (AQC) method. Fatty acids in Monopterus albus water extracts were esterified using transesterification method to form FAMEs before analyzed using GC. Boron trifluoride-methanol reagent was used for transesterification. The result of the study showed that Monopterus albus water extracts contain 15 kinds of amino acids and 9 kinds of fatty acids. The major amino acids in the extract are glycine $(5.26 \mathrm{mg} / \mathrm{g})$, alanine $(4.39 \mathrm{mg} / \mathrm{g})$, phenylalanine $(2.16 \mathrm{mg} / \mathrm{g})$, lysine $(1.88 \mathrm{mg} / \mathrm{g})$, proline $(1.84 \mathrm{mg} / \mathrm{g})$ and arginine $(1.73 \mathrm{mg} / \mathrm{g})$. While the major fatty acids in the extract are oleic acid $(192.23 \mu \mathrm{g} / 5 \mathrm{~g})$, palmitic acid $(184.48 \mu \mathrm{g} / 5 \mathrm{~g})$ and pentadecanoic acid (154.03 $\mu \mathrm{g} / 5 \mathrm{~g})$.
\end{abstract}

Keywords: Monopterus albus, Eel, Amino Acids, Fatty Acids

(C) RASĀYAN. All rights reserved

\section{INTRODUCTION}

The diversity of nutrients in food is not only necessary to meet nutritional needs, but also play a role in the immune system. Foods that contain good nutrients will boost the immune system and speed up the healing process. Amino acids and fatty acids are part of the essential nutrients for the body. Amino acids and fatty acids can accelerate the healing process of several diseases, especially tissue damage such as burns. ${ }^{1-5}$

Monopterus albus are rich in amino acids and fatty acids. Besides being used as food, Monopterus albus are also used in medicine. Monopterus albus oil contains fat $1.77 \mathrm{~g} / \mathrm{g}$ fillet and DHA $9.4 \mathrm{~g} / 100 \mathrm{~g}$ of oil. This DHA content is proportional to the content of DHA cod heener and salmon ${ }^{6}$. Razak ${ }^{7}$ get the fat content in Monopterus albus meat is 0.5 to $1.06 \mathrm{~g} / 100 \mathrm{~g}$ fillet and at head 0.4 to $0.78 \mathrm{~g} / 100 \mathrm{~g}$ tissue. The main fatty acid content is palmitic acid, arachidonate and DHA. Water extract from Monopterus albus mucus contains anti-fungi that can inhibit the growth of Candida albicans, Candida krusei, Cryptococcus neoformans, and Fusarium species. ${ }^{8}$ Bacteriostatic and bactericidal effect of Monopterus albus extract comparable to Channa striatus extract. Its anti-fungal effect is weaker and its antiproliferative effect is stronger than Channa striatus extract. ${ }^{9}$ Monopterus albus are also known to contain proteins. Monopterus albus amino acids are highly varied. ${ }^{10}$ In this study was determined the amino acids and fatty acids content in Monopterus albus water extracts.

\section{Materials and Methods}

\section{EXPERIMENTAL}

Monopterus albus was bought in Bukittinggi, Indonesia. Materials and instruments that were used for amino acids and fatty acids analysis could refer to Febriyenti et al. ${ }^{11}$ Monopterus albus was washed, discarded head and contents of its stomach. Clean Monopterus albus was cut to the size of approximately $2 \mathrm{~cm}$. Monopterus albus $(1 \mathrm{~kg})$ was extracted with $1 \mathrm{~L}$ distilled water in an autoclave at $121{ }^{\circ} \mathrm{C}, 1 \mathrm{~atm}$ for 15 minutes. Monopterus albus water extract was obtained by separating the Monopterus albus flash and

Rasayan J. Chem., 12(3), 1591-1594(2019)

http://dx.doi.org/10.31788/RJC.2019.1234071

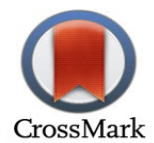


RASĀYAN J. Chem.

Vol. 12 | No. 3 |1591 - 1594| July - September | 2019

the water extract. Water extract was used for amino acids analysis. While for fatty acids analysis was used the dry extract. The dry extract was produced by drying the water extract using freeze dryer.

Amino Acids Analysis

Amino acids were analyzed using precolumn derivatization with 6-aminoquinolyl-Nhydroxysuccinimidyl carbamate (AQC) method. Details of analysis refer to Febriyenti et al. ${ }^{11}$

\section{Fatty Acids Analysis}

Fatty acids in Monopterus albus water extracts were esterified using transesterification method to form FAMEs before analyzed using GC. Boron trifluoride-methanol reagent was used for transesterification. Details of analysis refer to Febriyenti et al. ${ }^{11}$

\section{RESULTS AND DISCUSSION}

There are 20 monomer amino acids that build protein by polypeptide bonding ${ }^{12,13,14,15}$. Amino acids were determined using HPLC. Components and percentage of amino acids in Monopterus albus extracts could be seen in Table-1. The major amino acids content in Monopterus albus extracts were glycine, alanine, phenylalanine, lysine, proline and arginine.

Table-1: Amino Acids Contents in Monopterus albus Extracts

\begin{tabular}{c|c|c|c|c|cc}
\multicolumn{3}{|c|}{ Table-1: Amino Acids Contents in Monopterus albus Extracts } \\
\cline { 3 - 7 } No & \multirow{2}{*}{ Amino acid } & \multicolumn{5}{c}{ Contents (mg/ g extract) } \\
\cline { 3 - 7 } & Aspartic acid & 0.46 & 0.52 & 0.58 & 0.52 & \pm 0.06 \\
\hline 1 & Serin & 0.88 & 0.92 & 0.96 & 0.92 & \pm 0.04 \\
\hline 2 & Glutamic acid & 1.23 & 1.23 & 1.24 & 1.23 & \pm 0.01 \\
\hline 3 & Glycine & 4.50 & 5.71 & 5.57 & 5.26 & $\pm 0.66^{(1)}$ \\
\hline 4 & Histidine & 1.10 & 1.17 & 0.00 & 0.76 & \pm 0.66 \\
\hline 5 & Arginine & 1.74 & 1.74 & 1.70 & 1.73 & $\pm 0.02^{(6)}$ \\
\hline 6 & Threonine & 1.27 & 0.00 & 0.00 & 0.42 & \pm 0.73 \\
\hline 7 & Alanine & 4.32 & 4.43 & 4.42 & 4.39 & $\pm 0.06^{(2)}$ \\
\hline 8 & Proline & 2.00 & 1.82 & 1.71 & 1.84 & $\pm 0.15^{(5)}$ \\
\hline 9 & Tyrosine & 0.24 & 0.29 & 0.22 & 0.25 & \pm 0.04 \\
\hline 10 & Valine & 1.24 & 1.37 & 1.47 & 1.36 & \pm 0.12 \\
\hline 11 & Lysine & 1.86 & 1.93 & 1.86 & 1.88 & $\pm 0.04^{(4)}$ \\
\hline 12 & Isoleucine & 0.39 & 0.00 & 0.00 & 0.13 & \pm 0.22 \\
\hline 13 & Leucine & 1.13 & 1.31 & 1.29 & 1.24 & \pm 0.10 \\
\hline 14 & Phenylalanine & 1.36 & 2.92 & 2.21 & 2.16 & $\pm 0.78^{(3)}$ \\
\hline 15 & & & & & & \\
\hline
\end{tabular}

Fish species are widely used as a source of protein and amino acids. ${ }^{16}$ When compared with Haruan fish extract (Channa striatus) ${ }^{11}$ and tuna extract (Thunnus albus), the main content of Monopterus albus extract is slightly different. From Table-2 it shows that amino acids contents in Monopterus albus extracts are quite high. The comparison of the amino acids contents in Monopterus albus extracts and Channa striatus extract has could be seen in Table-2.

Table-2: Comparison of Amino Acids Contents in Monopterus albus Extract (M) and Channa striatus Extract (C)

\begin{tabular}{c|c|c|c}
\hline \multirow{2}{*}{ No } & \multirow{2}{*}{ Amino Acid } & \multicolumn{2}{|c}{ Contents (mg/ 1 g extract) } \\
\cline { 3 - 4 } & & $\mathrm{M}$ & $\mathrm{C}$ \\
\hline 1 & Aspartic acid & 0.52 & $2.56^{(6)}$ \\
\hline 2 & Serin & 0.92 & 1.43 \\
\hline 3 & Glutamic acid & 1.23 & $4.56^{(2)}$ \\
\hline 4 & Glycine & $5.26^{(1)}$ & $6.01^{(1)}$ \\
\hline
\end{tabular}


RASĀYAN J. Chem.

Vol. 12 | No. 3 |1591 - 1594| July - September | 2019

\begin{tabular}{c|c|c|c}
\hline 5 & Histidine & 0.76 & 0.55 \\
\hline 6 & Arginine & $1.73^{(6)}$ & $3.02^{(4)}$ \\
\hline 7 & Threonine & 0.42 & 1.13 \\
\hline 8 & Alanine & $4.39^{(2)}$ & $3.34^{(3)}$ \\
\hline 9 & Proline & $1.84^{(5)}$ & $2.91^{(5)}$ \\
\hline 10 & Tyrosine & 0.25 & 0.24 \\
\hline 11 & Valine & 1.36 & 0.96 \\
\hline 12 & Lysine & $1.88^{(4)}$ & 2.07 \\
\hline 13 & Isoleucine & 0.13 & 0.67 \\
\hline 14 & Leucine & 1.24 & 1.65 \\
\hline 15 & Phenylalanine & $2.16^{(3)}$ & 1.01 \\
\hline
\end{tabular}

Components and percentage of fatty acids in Monopterus albus extracts could be seen in Table-3. The major fatty acids content in Monopterus albus extracts were oleic acid, palmitic acid and pentadecanoic acid.

Table-3 : Fatty Acids Contents in Monopterus albus Extracts

\begin{tabular}{c|c|c|c|cc}
\hline \multirow{2}{*}{ Fatty Acid } & \multicolumn{5}{|c}{ Contents $(\mu \mathrm{g} / 5 \mathrm{~g}$ extract) } \\
\cline { 2 - 6 } & $\mathrm{B} 1$ & $\mathrm{~B} 2$ & $\mathrm{~B} 3$ & \multicolumn{2}{c}{ Mean $\pm \mathrm{SD}$} \\
\hline C10:0 (Caproic acid) & 1.40 & 1.60 & 1.57 & 1.52 & \pm 0.11 \\
\hline C12:0 (Lauric acid) & 6.30 & 6.90 & 6.00 & 6.40 & \pm 0.46 \\
\hline C15:0 (Pentadecanoic acid) & 158.10 & 159.00 & 145.00 & 154.03 & $\pm 7.84^{(3)}$ \\
\hline C16:0 (Palmitic acid) & 187.00 & 186.45 & 180.00 & 184.48 & $\pm 3.89^{(2)}$ \\
\hline C16:1n-9 (Palmitoleic acid) & 4.80 & 4.95 & 4.76 & 4.84 & \pm 0.10 \\
\hline C18:0 (Stearic acid) & 48.70 & 46.00 & 49.80 & 48.17 & \pm 1.96 \\
\hline C18:1n-9 (Oleic acid) & 190.70 & 187.00 & 199.00 & 192.23 & $\pm 6.15^{(1)}$ \\
\hline C18:2n-6 (Linoleic acid) & 17.10 & 17.55 & 16.89 & 17.18 & \pm 0.34 \\
\hline C20:0 (Arachidic acid) & 7.40 & 7.46 & 7.28 & 7.38 & \pm 0.09 \\
\hline
\end{tabular}

From Table-4 it shows that fatty acids contents in Monopterus albus extracts are specific. The comparison of the fatty acids contents in Monopterus albus extracts and Channa striatus extract has could be seen in Table-4. Caproic acid, pentadecanoic acid and linoleic acid could be found in Monopterus albus extract but not found in Channa striatus extract. Linoleic acid that cound be found in Monopterus albus extract is one of the omega- 6 fatty acids that play important rule on wound healing processes.

Table-4: Comparison of Fatty Acids Contents in Monopterus albus extract (M) and Channa striatus extract (C)

\begin{tabular}{c|c|c}
\hline \multirow{2}{*}{ Fatty Acid } & \multicolumn{2}{|c}{ Contents $(\mu \mathrm{g} / 5 \mathrm{~g}$ extract) } \\
\cline { 2 - 3 } & $\mathrm{M}$ & $\mathrm{C}$ \\
\hline $\mathrm{C} 10: 0$ (Caproic acid) & 1.52 & - \\
\hline $\mathrm{C} 12: 0$ (Lauric acid) & 6.40 & 1.84 \\
\hline $\mathrm{C} 15: 0$ (Pentadecanoic acid) & $154.03^{(3)}$ & - \\
\hline $\mathrm{C} 16: 0$ (Palmitic acid) & $184.48^{(2)}$ & $246.83^{(1)}$ \\
\hline $\mathrm{C} 16: 1 \mathrm{n}-9$ (Palmitoleic acid) & 4.84 & $75.32^{(2)}$ \\
\hline $\mathrm{C} 18: 0$ (Stearic acid) & 48.17 & $53.55^{(3)}$ \\
\hline $\mathrm{C} 18: 1 \mathrm{n}-9$ (Oleic acid) & $192.23^{(1)}$ & 36.53 \\
\hline C18:2n-6 (Linoleic acid) & 17.18 & - \\
\hline C20:0 (Arachidic acid) & 7.38 & 4.11 \\
\hline
\end{tabular}

The content of amino acids and fatty acids from Monopterus albus extract is commercially valuable. The glycine is a major component of collagen. Alanine strengthens cell membrane. Proline is the basic ingredient of glutamic acid. Glutamine is used by the inflammatory cells within the wound for proliferation and as a source of energy. Fibroblasts use glutamine for protein and nucleic acid synthesis 
RASĀYAN J. Chem.

Vol. 12 | No. 3 |1591 - 1594| July - September | 2019

${ }^{17,18}$. Lycine and vitamin $\mathrm{C}$ will form an important collagen tissue to maintain skin beauty ${ }^{1,2}$. Arginine is essential for efficient wound repair and immune function ${ }^{19,20}$. Fatty acids have an important function for the body. Eicosanoids are used to preserve the structural parts of the cell membrane and to produce ingredients such as a hormone. Eicosanoids help regulate blood pressure, blood clotting processes and immune responses to wounds and infections. Fatty acids play a role in repairing damaged tissue, development of brain nerve, wound healing agent and antithrombotic. In wound healing, fatty acids and proteins work together in the formation of keratinocytes and fibroblasts ${ }^{21,22}$. The fatty acid components of Monopterus albus extract are needed in the wound healing process.

\section{CONCLUSION}

Monopterus albus water extracts contain 15 kinds of amino acids and 9 kinds of fatty acids. The major amino acids in the extract are glycine $(5.26 \mathrm{mg} / \mathrm{g})$, alanine $(4.39 \mathrm{mg} / \mathrm{g})$, phenylalanine $(2.16 \mathrm{mg} / \mathrm{g})$, lysine $(1.88 \mathrm{mg} / \mathrm{g})$, proline $(1.84 \mathrm{mg} / \mathrm{g})$ and arginine $(1.73 \mathrm{mg} / \mathrm{g})$. While the major fatty acids in the extract are oleic acid $(192.23 \mu \mathrm{g} / 5 \mathrm{~g})$, palmitic acid $(184.48 \mu \mathrm{g} / 5 \mathrm{~g})$ and pentadecanoic acid $(154.03 \mu \mathrm{g} / 5 \mathrm{~g})$. These amino acids and fatty acids have good potential to accelerate the wound healing.

\section{REFERENCES}

1. G. Corsetti, G. D'Antona, F. S. Dioguardi and R. Rezzani, Acta Histochemica 112 (5), 497(2010), DOI:10.1016/j.acthis.2009.05.003

2. S. Guo and L. A. DiPietro, J Dent Res 89 (3), 219(2010), DOI:10.1177/0022034509359125

3. V. Ahuja, M. Rizk and A. Barbul, in Nutrition and Wound Healing, edited by J. Molnar (CRC Press, Boca Raton, p. 87-98 (2007)

4. M. L. Dylewski and Y.-M. Yu, in Nutrition and Wound Healing, edited by J. Molnar, CRC Press, Boca Raton, p. 49-64. (2007)

5. M. B. Schoemann, C. D. Bechtold, S. Agarwal and C. W. Lentz, in Nutrition and Wound Healing, edited by J. Molnar, CRC Press, Boca Raton, p. 65-86. (2007)

6. K. Endinkeau and T. K. Kiew, Pertanika J. Trop. Agric. Sci. 16 (3), 215(1993),

7. Z. K. A. Razak, M. Basri, K. Dzulkefly and C.N.A, Malaysian Journal of Analytical Sciences 7 (1), 217(2001)

8. M. Ikram and B. H. Ridzwan., International Research Journal of Pharmacy and Pharmacology 3 (1), $1(2013)$

9. A. Atif, M. Zahri, A. Esa, B. Zilfalil, U. Rao and S. Nordin, Journal of Applied Pharmaceutical Science 5 (1), 42(2015), DOI: 10.7324/JAPS.2015.50108

10. A. S. Tay, L. Shit, F. Chew and K. I. Yuen, Journal of Experimental Biology 206, 2473(2003).

11. Febriyenti, L. Laila and S. Baie, Pak. J. Pharm. Sci. 25 (1), 1(2012)

12. R. K. Murray, K. G. Daryl, C. D. Joe, A. M. Peter and W. R. Victor, Harper's Illustrated Biochemistry, 26 ed. McGraw-Hill Companies, Inc., New York, (2003).

13. M. C. Aristoy and F. Toldra, in Handbook of Food Analysis, edited by L. M. L. Nollet, Marcel Dekker, Inc., New York, Vol. 1, p. 83 - 123 (2004)

14. P. Furst and P. Stehle, The Journal of Nutrition 134 (6), 1558S(2004)

15. P. J. Reeds, The Journal of Nutrition 130 (7), 1835S(2000), DOI: 10.1093/jn/130.7.1835S

16. A. S. Babji, S. Fatimah, M. Ghassem and Y. Abolhassani, International Food Research Journal 17, 303(2010)

17. D. MacKay and A. L. Miller, Alternative Medicine Review 8 (4), 359(2003)

18. J. Z. Williams and A. Barbul, Surg. Clin. N. Am. 83, 571(2003), DOI:10.1016/S00396109(02)00193-7

19. A. A. Shepherd, Nursing Standard 18 (6), 55(2003).

20. A. Barbul, G. Rettura, S. M. Levenson and E. Seifter, Am. J. Clin. Nutr. 37, 786(1983).

21. N. Collins and C. Sulewski, in Nutrition 411 (Ostomy Wound Management., 2011)

22. A. Storey, F. McArdle, P. S. Friedmann, M. J. Jackson and L. E. Rhodes, Journal of Investigative Dermatology 124(1), 248(2005), DOI:10.1111/j.0022-202X.2004.23543.x

[RJC-4071/2019] 